\title{
ANALISIS KESULITAN MEMBACA PERMULAAN PADA SISWA KELAS II SEKOLAH DASAR
}

\author{
Riska Septiana Soleha ${ }^{1}$, Enawar $^{2}$, Dilla Fadhillah ${ }^{3}$, Sumiyani $^{4}$ \\ Universitas Muhammadiyah Tangerang, Kota Tangerang \\ 1riskanasoleha@gmail.com, ${ }^{2}$ enawar.abah@gmail.com, ${ }^{3}$ dillafadhillah89@gmail.com, \\ ${ }^{4}$ sumiyaninitura@gmail.com
}

\begin{abstract}
ABSTRAK
Fokus penelitian ini adalah faktor-faktor yang menjadi penyebab kesulitan membaca permulaan dan bagaimana kesulitan membaca permulaan yang dialami siswa kelas II di sekolah dasar. Tujuan penelitian untuk mengetahui faktor-faktor yang menjadi penyebab kesulitan membaca permulaan dan mengetahui kesulitan membaca permulaan yang dialami siswa kelas II di sekolah dasar. Penelitian ini menggunakan pendekatan kualitatifdengan metode analisis deskriptif sedangkan pengumpulan data yang dilakukan dengan menggunakan tes, observasi, wawancara dan dokumentasi. Teknik analisis data meliputi reduksi data, penyajian data, menarik kesimpulan. Pengecekan kebsahan data dilakukan dengan uji kreabilitas, pengujian transferabillity, pengujian dependability, pengujian konfirmability. Hasil dari penelitian menunjukan bahwa faktor yang menjadi penyebab kesulitan membaca permulaan faktor intelektual, faktor lingkungan, faktor psikologi (motivasi, minat, emosi) dan tingkat jenis kesulitan membaca permulaan beragam 1 siswa masih kurang mengenal huruf, 3 siswa masih membaca kata demi kata, 6 siswa kurang pemparafasean, 5 siswa masih kurang pelafalan, 5 siswa menghilangkan kata, tidak terjadi pengulangan membaca, 4 siswa melakukan pembalikan, 3 siswa meakukan penyisipan, 2 siswa melakukan penggantian makna, 1 siswa melakukan gerak belebihan, 5 siswa masih kesulitan konsonan, 2 siswa masih kesulitan vocal, 5 siswa masih kesulitan kluster.
\end{abstract}

Kata Kunci: Kesulitan membaca, membaca permulaan, siswa sekolah dasar.

\begin{abstract}
The focus of this research is the factors that cause difficulty in early reading and how difficult it is in early reading experienced by grade II students in elementary school. The purpose of the study was to determine the factors that cause early reading difficulties and to find out the initial reading difficulties experienced by second grade students in elementary school. This study used a qualitative approach with descriptive analysis method while data collection was carried out using tests, observations, interviews, and documentation. Data analysis techniques include data reduction, data presentation, drawing conclusions. Checking the validity of the data is done by testing the credibility, transferability testing, dependability testing, confirmability testing. The results of the study show that the factors that cause difficulty in early reading are intellectual factors, environmental factors, psychological factors (motivation, interest, emotion) and the level of difficulty in early reading varies 1 student is still not familiar with letters, 3 students are still reading word for word, 6 students lack paraphasing, 5 students still lack pronunciation, 5 students omit words, there is no repetition of reading, 4 students do inversions, 3 students do insertions, 2 students do meaning substitution, 1 student does exaggerated movements, 5 students still have consonant difficulties, 2 students still have vocal difficulties, 5 students still have difficulty clustering.
\end{abstract}

Keywords: Reading difficulties, beginning reading, elementary school students.

\section{PENDAHULUAN}

Pendidikan sekolah dasar merupakan jenjang awal untuk memulai pendidikan formal, jenjang sekolah dasar dibagi menjadi dua bagian yaitu: kelas rendah yang ditempuh dari kelas satu sampai kelas tiga, dimulai dari 
usia enam tahun sampai delapan tahun, sedangkan kelas tinggi ditempuh dari kelas empat sampai kelas enam, dimulai dari usia sembilan sampai sebelas tahun. Kebutuhan pendidikan sekolah dasar menjadi peran penting dalam membentuk kepribadian anak.

Sekolah dasar saat ini masih menggunakan Kurikulum 2013, Kurikulum 2013 mengajarkan anak agar menjadi berkarakter, cerdas, kreatif, inovatif dan terampil. Selain itu Kurikulum 2013 mencampurkan beberapa mata pelajaran seperti: Bahasa Indonesia, Matematika, Pkn, Ipa, Ips, Sbdp, Pjok menjadi satu kesatuan bernama tematik. Untuk pembelajaran tematik kelas tinggi mempelajari semua mata pelajaran sedangkan untuk pembelajaran tematik kelas rendah terdapat hanya beberapa mata pelajaran seperti: SBdP, PJOK, PKn, Matematika, dan Bahasa Indonesia.

Pembelajaran bahasa indonesia yang berada di jenjang sekolah dasar kelas rendah memfokuskan siswanya terlebih dahulu untuk memiliki keterampilan berbahasa, aspek keterampilan berbahasa yang harus dikuasai siswa yaitu menyimak, berbicara, menulis dan membaca.

Pada tahap membaca permulaan siswa kelas rendah akan diajarkan kegiatan mengenal huruf abjad serta cara membacanya, mengenal ejaan suku kata, belajar membaca kata dan belajar membaca kalimat. Seharusnya siswa yang berada di kelas dua sudah dapat membaca lancar, meskipun sudah dapat membaca lancar, siswa kelas dua tetap berada pada tahap membaca permulaan hanya saja pada kelas dua tahap ini difokuskan pada ketepatan intonasi membaca lalu mulai mengenal materi yang mengajarkan siswa untuk mengenal tanda huruf kapital, penggunaan simbol koma dan titik yang terdapat pada teks bacaan.
Menurut Dalman (2020) "Membaca permulaan bersifat mekanis yang dianggap berada pada urutan yang lebih rendah. Membaca permulaan merupakan suatu keterampilan awal yang harus dipelajari atau dikuasai oleh pembaca. Membaca permulaan adalah tingkat awal agar orang bisa membaca" (h.85).

Membaca permulaan dilakukan bertujuan agar siswa memiliki pengetahuan dasar yang dapat dipergunakan sebagai dasar untuk membaca bahasa indonesia dan diarahkan untuk memperkuuat kemampuan berbahasa lisan siswa. Dalam proses pembelajaran ketika praktik membaca sebuah tulisan telah ditemukan sejumlah masalah pada siswa, masalah yang sering muncul dalam kegiatan membaca masih terdapat ditemukan siswa kelas dua yang sepenuhnya belum cukup mempunyai kemampuan membaca yang baik dan lancar seperti, masih terdapat siswa yang membacanya mengalami kesulitan ketika menemukan kata "Ter" dan kata "Ng", "St" dan kata "Ny" sehingga ketika membaca menemukan kalimat yang terdapat pada kata tersebut mendadak menjadi tidak lancar, sering tertukar mengucapkan huruf "K" dan"X", "F" dan "V", sulit membedakan huruf kecil diantara "m","n" dan "w" sehingga sering terjadi pembalikan atau keliru ketika menemukan huruf tersebut saat membaca, meloncat kata atau huruf jika dirasa sulit untuk dibaca dan masih terdapat siswa yang benar-benar belum lancar sehingga masih perlu dampingan ketika membaca.

Menurut Suprani (2018) "Guru sering kali dihadapi pada anak yang mengalami kesulitan membaca khususnya di kelas rendah. Kesulitan-kesulitan tersebut antara lain: Kurang Mengenali Huruf, Membaca Kata Demi Kata, Pemparafase Yang Salah, Miskin Pelafalan, Penghilangan, Pengulangan 
Pembalikan, Penyisipan, Penggantian, Menggunakan Gerak Bibir, Jari Telunjuk dan Kepala, Kesulitan Konsonan, Kesulitan Vocal, Kesulitan Kluster, Diftong, dan Digraph" (h.84-88).

Kesulitan membaca permulaan yang dialami oleh siswa kelas dua, menggambarkan bahwa kondisi siswa tersebut belum mampu mengidentifikasi kata sehingga siswa memiliki keterlambatan membaca serta pemahaman yang masih kurang, tetapi hal ini juga memungkinkan adanya penyebab dan faktor-faktor lainnya sehingga siswa mengalami kesulitan membaca permulaan.

Menurut Rahim (2018) "Menyatakan faktor-faktor yang mempengaruhi membaca yaitu: Faktor fisiologi, faktor intelektual, faktro lingkungan, faktor psikologi (motivasi, minat, penyesuaian diri sosio dan emosi" (h.16-29).

Berdasarkan permasalahan yang tertulis di atas, maka penulis tertarik meneliti masalah tentang "Analisis Kesulitan Membaca Permulaan Pada Siswa Kelas II Sekolah Dasar" dan penelitian ini penting dilakukan karena membaca sebagai kemampuan utama bagi siswa kelas rendah agar dapat mengikuti kegiatan belajar mengajar dengan baik dan dapat membaca lancar tanpa kendala di kelas jenjang berikutnya sehingga bisa menyaring informasi dengan baik.

\section{METODE PENELITIAN}

Menurut Mawardi (2019) "Penelitian kualitatif menggunakan lingkungan ilmiah sebagai sumber data. Peristiwa-peristiwa yang terjadi dalam suatu situasi sosial merupakan kajian utama untuk penelitian kualitatif. Peneliti pergi ke lokasi tersebut, memahami dan mempelajari situasi. Studi dilakukan pada waktu interaksi berlangsung di tempat kejadian. Peneliti mengamati, mencatat, bertanya, menggali sumber yang erat hubungannya dengan peristiwa yang terjadi saat itu" (h.17). Intrumen penelitian ini menggunakan tes, observasi, wawancara dan dokumentasi. Dalam penelitian model analisis kualitatif menggunakan model Miles dan Huberman meliputi: Reduksi Data, Penyajian Data, Menarik Kesimpulan/Verifikasi. Tujuan dari penelitian ini yaitu untuk mengetahui Faktor-faktor yang menjadi penghambat membaca permulaan pada siswa kelas II di SDN Kembangan Utara 11 Petang dan Bagaimana kesulitan membaca permulaan yang dialami siswa kelas II di SDN Kembangan Utara 11 Petang.

\section{HASIL DAN PEMBAHASAN}

Pada kegiatan membaca permulaan yang dilakukan kepada 30 siswa di SDN Kembangan Utara 11 Petang telah ditemukan. Faktor-faktor lain yang dapat menjadi penghambat dalam membaca permulaan pada siswa kelas II yaitu berasal dari faktor intelektual pengetahuan cara melatih anak membaca, faktor lingkungan siswa yang kurang mendukung, faktor psikologi yang meliputi kurangnya atau menurunnya motivasi dari siswa, kurangnya minat siswa dalam membaca, kematangan emosi yang belum stabil sehingga belum dapat mengontrol diri siswa itu sendiri untuk melakukan kegiatan membaca. Kemudian Jenis-jenis kesulitan membaca permulaan yang dialami siswa berbeda-beda tingkat kesulitannya yaitu seperti masih terdapat 1 siswa masih kurang mengenal huruf, 3 siswa masih membaca kata demi kata, 6 siswa kurang pemparafasean, 5 siswa masih kurang pelafalan, 5 siswa menghilangkan kata, tidak terjadi pengulangan membaca, 4 siswa melakukan pembalikan, 3 siswa meakukan penyisipan, 2 siswa melakukan penggantian 
makna, 1 siswa melakukan gerak belebihan, 5 siswa masih kesulitan konsonan, 2 siswa masih kesulitan vocal, 5 siswa masih kesulitan kluster.

\section{KESIMPULAN DAN SARAN}

\section{Kesimpulan}

Berdasarkan hasil penelitian tentang analisis kesulitan membaca permulaan pada siswa kelas II di sekolah dasar, peneliti menarik kesimpulan bahwa. Kelancaran membaca seharusnya sudah dikuasai siswa kelas II untuk mempermudah mereka saat mengikuti kegiatan belajar mengajar di sekolah. Namun ternyata ditemukan siswa kelas II belum sepenuhnya dapat membaca dengan baik dan lancar, sehingga mereka masih memiliki kesulitan membaca ditahap membaca permulaan. Adapun yang mereka alami kesulitannya berdasarkan dari faktorfaktor lain serta jenis kesulitan membaca permulaan yang dialami siswa kelas II beragam.

\section{Saran}

Berdasarkan dari hasil kesimpulan maka peneliti memiliki saran untuk beberapa pihak yaitu:

1. Bagi guru

Peneliti harap kepada pihak guru di sekolah seharusnya guru lebih memberikan perhatian kepada siswanya untuk mengetahui detail jenis kesulitan siswa membaca permulaan yang dialami siswanya karena tingkat kesulitan membaca permulaan yang dialami siswa berbeda-berbeda jenisnya serta memberikan latihan membaca kepada siswa sesuai dengan jenis kesulitan yang dialami siswanya.

2. Bagi siswa

Peneliti harap kepada siswa kelas II di SDN Kembangan Utara 11 Petang, agar lebih giat dan menambah jam intensitasnya untuk berlatih atau melakukan kegiatan membaca meskipun keadaan sekolah sedang belajar di rumah sehingga kesulitan yang mereka alami akan berkurang atau bisa teratasi.

3. Bagi sekolah

Peneliti harap kepada pihak sekolah seharusnya ikut bekerja sama dengan guru dan memberikan solusi untuk membantu mengatasi kesulitan membaca permulaan yang dialami peserta didiknya.

4. Bagi peneliti

Peneliti harap untuk peneliti selanjutnya yang akan datang agar dapat menelusuri lebih luas tentang permasalahan yang mengenai faktor-faktor yang menjadi penyebab kesulitan membaca permulaan serta jenis-jenis kesulitan membaca permulaan yang dialami pada siswa di sekolah dasar.

\section{DAFTAR PUSTAKA}

Dalman. 2017. Keterampilan Membaca. Jakarta: $\quad$ PT RAAGAFINDO PERSADA.

Fatmasari Krisia Ria. 2018. Keterampilan Membaca. STKIP PGRI Bangkalan: Bangkalan.

Fadhilah,dkk. 2019. Pembelajaran Bahasa Indonesia Kelas Tinggi. Yogyakarta: Samudera Biru.

Fitria Nur Bunga. 2019. Analisis FaktorFaktor Penghambat Membaca Permulaan Pada Siswa Kelas I SD. Tangerang: Universitas Muhammadiyah Tangerang

Hadi Nur. 2016. Teknik Membaca. Jakarta: Bumi Aksara

Hassanudin Cahyo. 2016. Pembelajaran Membaca Permulaan Dengan Menggunkan Media Aplikasi Bamboomedia Gmgames Apps Pintar 
Membaca Sebagai Upaya Pembentukan

Karakter Siswa SD Mengahadapi Mea.

Vol 5 No 01. Hal 2. Jurnal Pedagogia.

Jumaris Martini. 2015. Kesulitan Belajar Bagi

Anak Usia Dini dan Usia Sekolah.

Bogor: Penerbit Ghalia Indonesia.

Kurniati, dkk. 2019. Pengaruh Metode Hands

On Activity Terhadap Kemampuan

Membaca Permulaan Siswa Kelas Satu

Sekolah Dasar. Vol 02 No 01. Hal 34.

Jurnal Sekolah Dasar.

Krisssandi Sagita Damai Apri. 2018.

Pendekatan Bahasa Indonesia Untuk

SD. Jakarta: Media Maxima.

Mawardi. 2019. Metode Penelitian

Pendidikan. Yogyakarta: Samudera biru.

Marlina. 2019. Assasmen Kesulitan Belajar.

Jakarta: Prenadamedia Group.

Pramesti Fitria. 2018. Analisis Faktor-faktor

Penghambat Membaca Permulaan

Pada Siswa Kelas I SD. Tulungagung:

STKIP Tulungagung.

Rahim Farida. 2018. Pengajaran Membaca

Di Sekolah Dasar. Jakarta: Bumi Aksara.

Rizkiana. 2016. Analisis Kesulitan Membaca

Permulaan Siswa Kelas I SDN

Bangunrejo 2 Yogyakarta. Yogyakarta:

Universitas Negeri Yogyakarta. Skripsi.

Satrianawati. Pendidikan Inklusi. 2019.

Yogyakarta: Grup Deepublish.

Subini Nini. 2011. Mengatasi Kesulitan

Belajar Pada Anak. Jogjakarta:

Javalitera.

Sugiyono. 2016. Metode Penelitian

Kuantitatif, Kualitatif, $\quad R n D$.

Yogyakarta: Cv Alfabeta.

2020. Metode Penelitian

Kualitatif. Yogyakarta: CV Alfabeta.
Sujarwaeni Wiratna V. 2014. Metodologi Penelitian. Yogyakarta: Pustaka Baru Press.

Suprani. 2018. Pembelajaran Bahasa Indonesia di Kelas Rendah Sekolah Dasar. Medan: Harapan Cerdas.

Windrawati. 2020. Analisis Faktor Penghambat Belajar Membaca Permulaan Pada Siswa Kelas I SD Inpres 141 Matalamag Kota Sorong. Vol 2 No 1. Hal 10. Jurnal Papeda.

Yani Ahmad. 2019. Kesulitan Membaca Permulaan Pada Anak Usia Dini Dalam Perspektiff Analisis Reading Readness. Vol 4 No 2. Hal 114. Jurnal Education. 